\title{
Use of science in British newspapers' narratives of climate change
}

\author{
Maria Laura Ruiu, Northumbria University, Department of Social Sciences, United Kingdom \\ Massimo Ragnedda*, Northumbria University, Department of Arts, United Kingdom \\ *Corresponding author: massimo.ragnedda@northumbria.ac.uk
}

\begin{abstract}
This paper investigates the use of science in British newspapers' narratives of climate change between 1988 and 2016. It is based on the analysis of eight newspapers and their Sunday and online versions (Daily Mail, Daily Mirror, The Daily Express, The Sun, The Times, The Daily Telegraph, The Guardian, The Independent). We used the keywords "climate/climatic change", "warm/warming" and "greenhouse/greenhouse effect" to retrieve the articles from the Nexis/Lexis database. To identify the articles with a specific focus on climate change, we included only those containing the keywords in the headline (9789 items). Framing theory helps interpret the process of construction of the "threat" through science by showing a tendency towards scientific consensus for the centre/left-leaning newspapers, and an instrumental use of consensus for the centre-right. These findings are useful for both scientists and policymakers interested in understanding how climate narratives can promote delay in action on climate change.
\end{abstract}

\section{Keywords}

climate framing, scientific frames, climate science communication, climate change, global warming

\section{Introduction}

The study of journalistic framing has been considered by some sociological approaches as relevant to interpret contemporary understanding of climate change (CC) also in relation to the different presentations of CC by media reporting. This means that scientific knowledge and content might be framed in a way that is subject to cultural "influences, political expectations, and narrative requirements" (Arnold, 2018, p. 38). This paper examines a potential evolution of themes associated with the use of scientific frames in British newspaper reporting and the prominent stories associated with the use of scientific frames over time by focusing on British newspapers reporting on CC between 1988 and 2016. The analysis is guided by narrative and framing theories. Narratives are usually considered at a macro-level in which the interpretation of the chronological facts is provided by the narrator(s), similarities among multiple narratives of the same events are identified and responses to "what" questions are provided. Framing tends to be associated with micro-perspectives, "how" questions and the interaction of different frames, which might also generate conflicts. However, "frames serve as the underlying foundations on which narratives are expressed" (Aukes, Bontje, \& Slinger, 2020, "Narrative and Storytelling' vs. 'Frame and Framing,", para. 1). Combining the two approaches, this paper investigates questions related to both how CC is scientifically framed and what the main narratives (and their evolution) are. Following Arnold (2018), the analysis of journalistic framing is relevant from a sociological point of view because media and scientific reporting tend to present the issue in different ways. This means that scientific knowledge and content might be framed in a way that is subject to cultural "influences, political expectations, and narrative requirements" (Arnold, 2018, p. 38). Since the 1990s, concerted research efforts have focused on the role of journalistic reporting in framing CC (Bell, 1994; Boykoff, 2014; Trumbo, 1996; Ungar, 1992; Weingart, Engels, \& Pansegrau 2000; Wilkins, 1993). The literature 
frequently holds mass media responsible for mediating communication processes between science, policy, and the public, by presenting both causes and consequences of CC, thus influencing public opinion and influencing climate governance (Boykoff, 2009; Rick, Boykoff, \& Pielke, 2011). This suggests that journalistic reporting can frame CC science as "good" or "bad" science, by emphasising, or by contrast diminishing, specific aspects of the phenomenon. Therefore, the guiding research question of this paper relates to "how" newspapers use science to represent CC-related issues and to narrate the "what". This work focuses on British newspapers because, despite an increasing number of challenges in news production (e. g., migration of news consumers to online platforms), the UK newspaper industry still reaches most of the UK population (Mediatique, 2018), and $90 \%$ of adults in Great Britain consume either print or online newspapers (NRS, 2017). Nevertheless, in the context of CC, the literature shows that UK newspapers give space to a plurality of voices even though they represent a minority (Boykoff \& Mansfield, 2008; Painter \& Gavin, 2015). Finally, news articles are more comprehensive in terms of both reporting existing online discourses and introducing issues / content on the public agenda (Hellsten \& Vasileiadou, 2015).

The first section of the paper presents the study background and a literature review on framing CC. The second section describes the method used for both selecting and analysing a sample of articles. The third section (and its related sub-sections) reports the results of a thematic analysis that explores the themes connected to the use of scientific frames. The final section discusses the results and suggests some implications.

\section{Study background}

The First World Climate Conference in 1979 urged governments to tackle CC as a world problem (UNFCCC, 2006). Later, the first report by the Intergovernmen- tal Panel on Climate Change (Houghton, Jenkins, \& Ephraums, 1990) identified the need for framing the global climate crisis as the most urgent environmental problem. The IPCC First Assessment Report in 1990 identified some areas of uncertainty that derive from several factors (Rice, Gustafson, \& Hoffman, 2018) related to both the evolution of the phenomenon and the exact impact of CC. CC discourses rely on scientific knowledge, but also media frameworks (Rhomberg, 2010). Entman (1993, p. 52) describes the framing process as a selection of some aspects that make a piece of news memorable by providing "problem definition, causal interpretation, moral evaluation, and / or treatment recommendation for the item described". Framing has been conceptualised in many ways, especially in relation to media effects theory. On the one hand, the media has been defined as recipients of external content, which is interpreted by individuals and "crystalised" by journalists in the public discourse (Gamson \& Modigliani, 1989). On the other hand, they have been recognised to contribute towards constructing social reality by framing reality in a "patterned way" (McQuail, 1994, p. 331). These dynamics have been described as the "framing effect", that refers to changes produced in terms of public opinion by the presentation of an issue in certain ways (Chong \& Druckman, 2007). However, in both cases, despite a different intensity of the effects produced, the media are held responsible for filtering and channelling the interpretation of such reality (Scheufele, 1999). The literature also suggests that a framing effect will vary according to several factors including the context (e.g., one-sided context or competition with other frames). This is particularly evident in reporting on environmental issues (Griffin \& Dunwoody, 1997) when several interpretations of the variety of scientific perspectives are provided by intermediate actors, among whom the media play a significant role (Berglez, 2011; Brüggemann, 2014; Gibson, Craig, Harper, \& Alpert, 2015). This suggests that the media actively contribute to the definition of a social problem (Trumbo, 1996), here 
intended as a particular situation that is perceived by the public as outside socially shared norms, and needs to be targeted by policies (Gusfield, 1989). In this direction, the media provide the public with specific interpretations of science (Rahmstorf, 2012). In the specific case of reporting on climate change, frames are defined as a scientific angle by the journalist (Griffin \& Dunwoody, 1997) who legitimises specific voices that speak about the climate (Boykoff, 2013; O'Neill, 2013). They select and establish who the "experts" are and promote specific ways of conceptualising CC (O’Neill \& Smith, 2014; Rebich-Hespanha, Rice, Montello, Retzloff, Tien, \& Hespanha, 2015). Therefore, since the complexity of CC is difficult to be communicated by the media (Anderson, 1997), the media might adopt scientific frames to emphasise specific aspects, (in)action and voice, but it does not necessarily mean that they rigorously report scientific findings. Previous studies highlighted that mass media tend to represent a conflict in climate science by giving a "disproportionate" space to contrarian voices even though they represent the minority within the scientific community (Akerlof, Rowan, Fitzgerald, \& Cedeno, 2012; Boykoff, 2013; Rahmstorf, 2012). In turn, this produces inaccuracy (Shaw, 2013; Vestergård, 2011) and distortion of scientific results (Höppner, 2010; Jennings \& Hulme, 2010). Given these premises, the overall aim related to the use of science in CC reporting is articulated in two main sub-questions. The first question relates to the evolution of CC scientific frames in British newspaper reporting over time:

RQ 1: How have scientific frames of CC evolved in British newspaper reporting?

Framing provides interpretive packages schemas (Gamson \& Modigliani, 1989; Scheufele \& Tewksbury, 2007) of CC, that may explicitly or implicitly promote specific pathways of action / inaction (Moser, 2010). Framing is intended here as "the process which implies a strategic selection (conscious or not) of language features for a particular purpose" (Fløttum \& Gjerstad,
2017 , p. 2). Specifically, the definition of scientific frames provided by Severson and Coleman (2015) is based on positive and negative forms. However, while the authors specifically refer to CC consequences (e.g., scientific frames that highlight positive or negative consequences of action / inaction), we consider the multidimensionality of CC as represented by news media using science. Therefore, this work identifies scientific frames based on the adoption of scientific voices and reporting of scientific studies in the corpus of the news articles to support the multidimensional narrative of CC.

Scientific consensus around the existence of CC and its anthropogenic causes has been increasingly recognised in media reporting (Boykoff, 2007; Gibson et al., 2015; Grundmann \& Scott, 2014; Jang \& Hart, 2015). In the UK, elite newspapers (2000-2010) were found to represent specific voices that speak for the climate with a combination of processes of politicisation and journalistic logics (Matthews, 2015), defined as the routinised process through which the journalists "construct" (Tuchman, 1978) and communicate information (Altheide \& Snow, 1988). However, in CC reporting, in addition to both political valence and media logics, at least a third dimension has been identified in scientific terms. In fact, media routines interact with both climate science and political valence to represent the reality of climate change (Kunelius, 2014). Some approaches have contextualised the intersection between these three levels in the neoliberal scenario by attributing to the press culture a tendency to politicise public matters and represent conflictual instances between political and scientific campaigning. In turn, such a dichotomic representation produces an image of both scientists and politicians as self-interested (Cappella \& Jamieson, 1997) and focused on their own agenda rather than on public matters. CC, translated in such "media logic" (Berglez, 2011), becomes a mediated political event (Akerlof, Rowan, Fitzgerald, \& Cedeno, 2012). Therefore, media construction of climate news in scientific terms means that the scientific frames are also infused 
of political connotation, that is in turn embedded in a neoliberal scenario in which sceptics and advocates contend the meaning of CC (Berglez, 2011).

Looking at the evolution of climate narratives in 1988, the UK press represented CC as a multidimensional threat caused by both human and "non-human" processes (e.g., solar sunspots). After 1988, CC narratives started to be influenced by the partisan nature of the debate (Carvalho, $2005,2007)$. The mutability of the media representation of CC and the multidimensionality of the phenomenon progressively produced uncertain scenarios firstly about the causes of CC, and then about the effects and actions needed (Grundmann \& Scott, 2014; Nerlich \& Jaspal, 2014; Painter \& Ashe, 2012; Painter \& Gavin, 2015). White (1981) suggests that narrative becomes a problem when the real events are translated into the form of a story. This happens when the events, such as in the case of historical chronological facts, are not capable to offer themselves as stories. However, this can be also applied to scientific facts, such as e.g., CC, when the "objectivity" of the science might be narrated through the "subjectivity" of a narrative. Narrative scholars distinguish between structural elements, such as verbal units (Labov \& Waletzky, 1997), form, such as genre (Smith, 2005), and content (Jones \& McBeth, 2010) of the narrated stories (Arnold, 2018; White, 1987). The definition of narrative adopted here refers to the definition of problems, by identifying causes, responsibilities, and possible solutions (Fløttum \& Gjerstad, 2017). This means identifying some communalities among CC stories, narrated by news media, in terms of context, actors presented (villain, heroes, and victims), a plot and (moral) action needed to deal with the effects of the situation narrated (Arnold, 2018). Therefore, the analysis of the narrative is based on an approach that is content-focused and identifies the main topic of a narrative, which in turn allows identifying the active actors, their relationships and actions (Polletta, 2006).
This is directly connected to the second question that investigates the themes associated with the use of scientific frames:

RQ 2: What are the prominent stories associated with the use of scientific frames over time?

The analysis of the topics associated with the use of scientific frames is relevant to understand what topics and aspects of every day are associated with the scientific construction of CC.

\section{Methods}

British newspapers were chosen owing to the primary role played by Britain in the international politics of CC. Moreover, its news articles are often reproduced by English-speaking print media around the world (Painter \& Gavin, 2015). The news articles analysed in this work were retrieved from eight newspapers, and their Sunday and online versions, with highest circulation rates (Daily Mail, Daily Mirror, The Daily Express, The Sun, The Times, The Daily Telegraph, The Guardian, The Independent). Tabloids, that reach large segments of the population, and news and editorials that inform readers about CC were included to provide a comprehensive picture (Boykoff, 2007; Boykoff \& Mansfield, 2008). Following Carvalho (2007), articles containing the keywords "climate / climatic change", "warm / warming" and "greenhouse/greenhouse effect" in the headlines were retrieved from the Nexis / Lexis database (9789 items). The articles were grouped into three blocks (1988-1997; 1998-2007; 2008-2016) (Table 1). The periods used to observe potential differences across the three blocks were defined in relation to significant shifts described by the literature as drivers for change in climate discourse. The start and end of the first block respectively correspond to the IPCC institution and the definition of the Kyoto Protocol (Carvalho, 2007). Moreover, the end of the second block coincides with the emergence of catastrophe discourses (related to the consequences of CC) in UK 
newspaper reporting (Doulton \& Brown, 2009), which suggests a shift towards increasing recognition of the reality of CC. Therefore, from a conceptual standpoint, a sort of "maturation" to take place in the journalistic treatment of the issue can be expected. Finally, the Paris Conference (December 2015) represents a historical shift in climate discourse in relation to the definition of responsibilities and binding and tailored targets (Kinley, 2017). The final sample was generated as the ratio between the total number of items included in the block and the number of articles (NItems / NSample), and chronologically extracted (Boykoff \& Boykoff, 2004). This also allowed for respecting the fluctuation of the number of articles over the entire period (the sample was larger in years with higher news coverage, see Table 1 ).

A combination of thematic and narrative analysis on the three periods investigated potential differences across the blocks. Drawing on narrative methods, we explored the evolution of the main themes to examine the development of a "plot" throughout a temporal scale (Floersch, Longhofer, Kranke, \& Townsend, 2010). The narrative structure was explored by looking at the actors, motives, and actions in a setting. The exploration of multiple articles supports an understanding of a "meta-narrative" over time (Bishop, 2001). Once the main themes were identified, we recorded the characters, scene, temporal development and actions described (Foss, 1996). These were explored under the overall plot development. Using Bishop's approach (2001), we focused on the identification of the main themes to explore these dominant elements.

Since narratives are interpreted as a view of the world in a particular way (Foss, 1996), the narrative analysis was complemented by the exploration of the scientific frames adopted to "shape" such narratives. The analysis focused on the identification of actors (with scientific "framing power", both subject or object of the discourse) and "themes (and sub-themes)", and how they combine in framing strategies. Scientific frames are intended as a conflictual representation of CC-related aspects that are justified by scientific arguments and characterised by positive or negative connotations (Severson \& Coleman, 2015). We identify a scientific frame whenever a news article includes references either to scientists or to scientific findings within the corpus to explore how they are integrated into broader narratives about CC. An article is classified as adopting a scientific frame when scientists or their findings are used to make some arguments and aspects salient. The following example shows how scientists can be used to support a relation between diseases and warming climate: "Scientists say diseases including dengue fever and the West Nile virus could become common as warmer weather attracts insects from parts of Asia and Africa" (Batchelor, 2015). The themes were identified through an inductive approach based on reading the articles several times and classifying the emergent topic supported by climate science.

Table 1: Sample of articles extracted per block of years

\begin{tabular}{lcr}
\hline Years & N Items & n Sample \\
\hline 1988-1997 & 396 & 197 \\
1998-2007 & 1933 & 389 \\
2008-2016 & 7460 & 372 \\
Total & 9789 & 958 \\
\hline
\end{tabular}

\section{Results}

The use of science to justify news articles narratives was found in 308 cases. Table 2 shows an increase in the adoption of science across the three blocks. A first characteristic, emerging from this table, relates to the existence of different themes in relation to the political orientation of newspapers. Given this peculiarity, the following sections discuss the specific themes that emerged by also considering two macro-areas related to centre-left (Daily Mirror, The Guardian, and The Independent) and centre-right (Daily Mail, The Daily Express, The Sun, The Times, and The Daily Telegraph). Given the difficulty of attributing a precise political orientation to newspapers, as highlighted by the litera- 
ture (Edwards \& Cromwell, 2006), the two macro-areas were identified through the classification provided by YouGov (2017). The newspapers were selected based on circulation rates. Therefore, the number of newspapers that belong to the centre-left (CL) and centre-right (CR), as well as the number of articles, is unbalanced because it reflects the real number of articles published in the entire period. However, the analysis of the opinion-leading press can provide a robust picture of how British newspapers adopt climate science to support their narratives. The Online Supplement provides a summary of the emergent themes, their frequencies, and examples.

Table 2: Distribution of articles that adopt science across the three blocks

\begin{tabular}{lccr}
\hline Years & N Items & Centre-right & Centre-left \\
\hline $1988-1997$ & 65 & 10 & 55 \\
1998-2007 & 116 & 31 & 85 \\
2008-2016 & 127 & 49 & 78 \\
Total & 308 & 90 & 218 \\
\hline
\end{tabular}

\subsection{Centre-left scientific frames}

Four macro themes emerge from the analysis of the CL articles across the three blocks (see Online Supplement A).

A first macro-theme emphasises the scientific consensus around the causes of the problem and its future consequences by representing the scientific community as a unique voice / character of the narrative. This happens from the first block and continues throughout the period under consideration by using expressions such as "most scientists" (King, 2005) and "the evidence is mounting all-round" (The Independent, 2011). Within the consensus macro-area, two main sub-themes, which also set the scene and point out the action needed, can be identified related to i) consensus around risks / consequences and visible signs of CC (scene); ii) adaptive capacity of society (also through geoengineering technology) as a moral issue (action).

The first sub-theme shows the use of scientific frames to attribute ecological variations to $\mathrm{CC}$, as well as impacts on both humans and nature. These articles set a scene in which CC is a risk with "longterm effects" (Lean, 1995), and even when they list some potential benefits, they frequently mention negative consequences (Macalister, 2004). Such representation of the severity of CC consequences increases across the three blocks. The third block shows an evolution of the narrative in which climate science is often represented as settled around both causes and consequences of CC, which will cause "drastic harm" (Connor, 2007). A sense of urgency is emphasised due to the evident symptoms of CC such as e. g., melting "polar ice sheets" (Ashdown, 2012), hot waves records (Connor, 2014) and rising of "temperatures" (Connor, 2016).

Scientific evidence also supports a second sub-theme related to the adaptive capacity of both ecological and human systems to changes. The second block confirms that the environment can be better understood by investing in research. Negative predictions about the impact of CC are often counterbalanced by positive messages about the possibility of limiting the damage if current practices are corrected (Vidal, 2006). However, CC is predominantly represented as a risk that can cause "turbulence" (Pearce, 2006) in both human and natural systems. In the third block, even though delay in action might cause devastation, scientists are confident that there is "still time to take meaningful actions to reduce the impact" of CC (Abraham, 2016). Especially in the third block, the action becomes a "moral obligation" that involves global and social justice-related challenges (Brown, 2012).

A second macro-theme describes the scientists-characters as political and economic advisors, who encourage / support the reduction of greenhouse gases through new policies and economic strategies (Brown, 2000), and criticise some political choices (Pilkington, 2008). The second block confirms this tendency to use science either to support interdisciplinary efforts for implementing energy-related measures (Elliott \& Seager, 2007) or to criticise political directions (The Guardian, 2007). The third block further encourages 
economic actors and policymakers to collaborate with scientists to implement market regulation and invest in mitigation and sustainable production systems (Moodie, 2015).

A third macro-theme can be labelled as "confutation of scepticism", which sets a scene in which scepticism is described as underpinning political-economic interests in defending oil industry activity, delaying action and disseminating misleading information. Economic and political interests are held responsible for spreading scepticism (Vaughan, 2010) and for stoking inexistent scientific controversies to delay action (Monbiot, 2009) across the three blocks. Especially in the third block, defensive tones are adopted to respond to "accusations" such as e.g., in the case of the "Climategate scandal" of November 2009 (release of more than a thousand emails and documents hacked from the University of East Anglia (see Leiserowitz, Maibach, Roser-Renouf, Smith \& Dawson 2012). Defensive tones can be found e.g., when responding to sceptics' attempts to "show that much of our recent CC is just natural" (Abraham, 2014).

Finally, a fourth macro-theme includes articles that reference both "sceptical" and "advocate" positions or refer to sceptical positions. This happens e.g., when referring to "disagreement" among scientists (McKie, 2007), a "poisoned debate" (Adam, 2010, p. 30), "exaggerated" forecasts (Nicholson-Lord, 1990) and a "receding certainty" (Pearce, 1993). In the second block, e.g., one article questions the anthropogenic causes of CC by both using mocking tones (Lawson, 2007) and referencing a documentary that contains some scientific mistakes (Boykoff, 2008). In the third block, some sceptical arguments about the impact of CC are reported and debated (Nuccitelli, 2014, 2015).

\subsection{Centre-right scientific frames}

Two main macro themes emerge from the analysis of the CR articles (see Online Supplement B).

A first macro-theme characterises a scene in which scepticism is narrated through three main sub-themes related to i) scientific disagreement among the scientist-characters who disagree around different aspects of climate science (e.g., existence, causes and consequences); ii) emphasis on scientific dishonesty behind the promotion of CC; and iii) scientific uncertainty around future impact and action to be taken.

The first sub-topic emphasises the existence of sceptical positions within the scientific community and contrasting understanding of CC about several aspects. There is a tendency to refer to natural fluctuations (McCarthy, 1989) and scientists' disagreement (Hosenball, 1990) around the causes and consequences of CC. Therefore, CC is described as a "myth" across the three blocks (Bellamy, 2004, p. 12; Daily Mail, 2002; Delingpole, 2009; Rose, 2013), and sceptics are surrounded by a scientific "aura" (Clark, 2013).

The second sub-theme expresses the dishonesty of climate scientists and sets a scene in which scientists manipulate scientific data to scare people and receive grants for their research. This topic emerges in the second block by e.g., describing scientists as "eco-doomsters" and climate science as "orthodoxy" (Phillips, 2006), and increases in the third block by quoting scientists who admit being "alarmist" about CC impact (Warren, 2014). In the second block, climate scientists are still described as a "lobby" (Jenkins, 2006) and "doom-mongers" (Hanlon, 2006), climate predictions are defined as "an art rather a science" (Simons, 1998). The third block more often accuses scientists of manipulating data to support their arguments (Delingpole, 2013) and "suppressing [dissenting] research" (Carter, 2014). Scientists are accused of receiving public money to produce studies that support tax increases. Uncertainty derives from science, which is not "settled" (Webb \& Smith, 2013).

The third sub-theme shows uncertainty about both the reality/severity of CC consequences and the need for intervention. Greenhouse effect and global warming are also described as potentially beneficial (Austin, 2016; Daily Mail, 1992; Lambie, 2005). Furthermore, policies that 
are based on "figures [that are not even] halfway believable" (Booker, 2009, p. 16; Webster, 2013) will cause economic damage. By contrast, CC may produce benefits for other characters of the narratives such as wine producers (Derbyshire, 2007), food producers (Beall, 2016; Prigg, 2014), producers of medical plants (Daily Mail, 1992) and the tourist sector (Batchelor, 2015; Graham, 2013).

A second macro-theme shows consensus/instrumental consensus. While some articles focus on scientific consensus around several aspects of CC, in other cases the consensus is "accepted" under certain conditions. These include the discussion of causes / consequences that are described as real (and sometimes catastrophic) if located in faraway places / scenes and distant in time, and the impossibility of tackling the problem.

A first sub-theme shows the use of "instrumental consensus". In this case, CC consequences mainly affect nature / animals (Austin, 2016; Smith, 2001) or result from natural processes (Daily Mail, 1994). These articles also locate the problem in an abstract future (Simons, 1997) that will affect the "world's poor" (Clover, 2007). In the second block, CC is often represented as real, but alarmist tones (e.g., "impacts of CC will be devastating”, Winter, 2004) emphasise the impossibility of acting. In the third block, a mixture of tones that range from extremely dramatic to reductive can be simultaneously found. In some cases, consensus might concern some aspects of $\mathrm{CC}$, but scientific findings are described as controversial and uncertain (Collins, 2013). Examples of this tendency are expressions such as "it is possible this can be related" (McCarthy, 1992b), "before they can make more accurate predictions" (Roy, 1989) and "some scientists believe" (McCarthy, 1992a). Moreover, even when scientific consensus emerges, the lack of cooperation of some international political actors transmits a message that it is difficult to act (Radulova, 2014; Stone, 2011; Thornhill, 2013).

The second use of consensus includes a genuine recognition of the existence of $\mathrm{CC}$ and its related negative consequences.
The need for intervention is emphasised, especially when supporting specific energy production systems (Hardy, 2004; Leake, 2005) and discussing market mechanisms (Pearce, 1990; Stone, 2011) and technological progress as potential solutions (Highfield, 2004; Searjeant, 2005; Spencer, 2014).

\section{Discussion and conclusions}

Different uses of scientific frames that shape specific narratives can be identified in relation to the political orientation of newspapers. Both groups of newspapers represent either consensus or scientific disagreement but in a different way. This is directly connected to the research questions of this paper related to the identification of a potential evolution of themes associated with the use of scientific frames. The exploration of themes enabled us to understand the scene and identify the characters, plot and potential actions associated with two different narratives characterised by specific political orientation, which are in turn backed up by the use of science / scientists.

Alongside some constant macro-traits, an evolution of both narratives can be observed, which for the CL increasingly embraces scientific certainty, whereas for the CR scientific confusion.

Across the three blocks, the CL supports a plot based on scientific consensus. Science tends to be used to frame a narrative that supports the existence, severity and need to act against CC. Previous studies (Lineman, Do, Kim, \& Joo 2015; Manzo, 2012) found that the adoption of positive messages and language enhances both public trust in scientists and support for CC policies (Feldman, Myers, Hmielowski, \& Leiserowitz 2014; Hmielowski \& Nisbet, 2016; Nisbet, Cooper, \& Garrett, 2015). Accordingly, CL newspapers channel positive messages to invoke intervention and conceive scientists as political / economic advisors. However, especially in the third block, "defensive tones" are often adopted to defend the rigours of science against sceptics' accusations. Scientific findings are also used to support a "morality" relat- 
ed to climate “(in)justice”, inequalities and duty to act to protect the environment and living being's existence.

In contrast, the CR newspapers often adopt scientific characters in their narrative who lack expertise in climate science (Dunlap \& McCright, 2010; Mulvey \& Shulman, 2015) and scientific language to either deny or question several aspects of the phenomenon. Some spokespersons, such as e.g., Philippe Stott (2003; Daily Mail, 2002; Matthews, 2003), are used to criticise policy intervention (Searjeant, 2004). In addition to questioning the scientific predictions about the effects of CC (Carter, 2014; Carpenter, 2011; Delingpole, 2011), the focus often shifts towards the economic impact of climate policies (Pearce, 1990; Stone, 2011) and the political nature of climate debate (Matthews, 2000; Radford, 2009). Starting from the second block, the scientific consensus increases, but the styles and arguments adopted suggest that scientific consensus can be used instrumentally. The combination of narratives that describe CC as out of human control and simultaneously refer to scientific uncertainty about the reality or the severity of these consequences, plus the description of consequences as potentially beneficial, contribute towards creating a confusing image. Scientific frames are also associated with damage to the natural environment and people who live in "faraway" places and thus are "invisible" (Ungar, 1995, 2001). Furthermore, the preference of CR newspapers for attributing responsibility to international commitments shifts the problem to a global arena (Ford \& King, 2015; Moser, 2014; Takahashi \& Meisner, 2013). This, in turn, further contributes towards creating an abstract image of a "faraway" problem. Therefore, the adoption of a "flood myth" style (von Burg, 2012), combined with the idea of the impossibility of acting, increases confusion. This is confirmed when the "status-quo" is explicitly and implicitly supported by using "uncertainty" to justify inaction on CC. The use of a scientific frame to support a narrative based on uncertainty about several aspects of CC might be interpreted in the light of a neoliberal press culture that is based on conflictual instances between political and scientific characters. This has been attributed to their focus on their own agenda rather than on public matters (Phelan, 2014). CC has been interpreted as a mediating topic that generates forms of reciprocal dependency between different spheres of society (in particular, politics, science, and mass media) (Rhomberg, 2010). Further, scientific framing of climate news also sets a "politicised" scene in which sceptics and advocates contend the meaning of climate change. Therefore, even when the main characters of such narratives are represented by scientists, their actions and messages tend to assume politicised meanings, which in turn reflect the conflicts of a neoliberal scene (Phelan, 2014). The uncertainty related to scientific findings and action needed in terms of policies tends to be exacerbated by the newspapers, which tend to distinguish those scientists who believe that CC is happening and will have significant consequences (CL), and those who are sceptic (CR) (Boykoff, 2013; Rahmstorf, 2012). However, this minority of sceptical scientists have been frequently found to be supported by oil corporations (Levy \& Rothenberg, 1999). While uncertainty is intrinsic to scientific models based on multiple different potential inputs used to predict future scenarios, and it is usually interpreted as a driver of progress (Corner, Whitmarsh, \& Xenias, 2012), Dunlap and McCright (2010; pp. 240-259) refer to a "manufacturing uncertainty" used to overshadow the need for environmental regulation.

These findings expand the literature on how media frames can become a vehicle of either support to climate science or sceptical perspectives that cast doubts around the need for policy action. In other words, the analysis demonstrates the existence of different narratives that might influence or reinforce the opinions of newspapers' readers, whose support is fundamental for policymaking. It should be also acknowledged that the literature on frames adopted by the media produced controversial results (Fahy, 2017). Some studies identified an evolution from a 
starting phase characterised by a "(false) balance" around the scientific consensus on CC (Boykoff \& Boykoff, 2004, p. 128), moving towards a disappearance over time in both the US and UK (Boykoff, 2007). By contrast, some other studies (e.g., Painter \& Gavin, 2015) highlighted a persistence of sceptical sources in the English context. However, these contradictory results might also be explained in the light of a shift of attention from reporting scientific conflicts around the causes towards the consequences of climate change and the action needed (Ruiu, 2021).

Science-driven changes might be challenging for governments and economies dependent upon fossil fuel resources (Dunlap \& Jacques, 2013; van Rensburg \& Head, 2017). The literature shows how the carbon-dependent "status quo" is promoted by the oil lobbies by creating ad hoc think tanks that channel their messages (by employing "unqualified scientists") through the mass media (McCright \& Dunlap, 2003; Moser, 2010) or responding to them to protect their own interests (Bacon \& Nash, 2012). Framing CC means combining multiple journalistic, public, scientific and political interpretations. For example, for the CL, Dominic Lawson (son of Nigel Lawson, a British conservative politician and journalist who founded the The Global Warming Policy Foundation, conservative think tank) criticises climate science and policy choices on CC (see e.g., Lawson, 2006, 2007, 2008). This suggests that, especially in the context of CC, editors, journalists and reporters unconsciously or consciously frame their narratives based on "interiorised" routines, which might also lead to inaccurately interpret the evolution of a phenomenon. Considering these individual interpretations in the context of the identified macro-tendencies, news workers might "interiorise" a routine in their work by combining and negotiating external pressure and their own perspectives (Berglez, 2011). However, it is not possible to speculate on newsroom mechanisms at this stage. This opens new questions for further investigation of the interplay be- tween external pressures, journalists' personal opinions, and knowledge about CC.

The role of narratives in influencing social life and mobilisation of people / resources has been recognised by the literature (see e.g., Bruner, 1991; Dahlstrom, 2010; Smith, 2010). Moreover, collective narratives tend to be influenced by news media, which tend to identify intentions, victims, villains, and heroes (Boholm, 2015). These findings further support studies showing that framing CC by using science to emphasise specific aspects, or by contrast neglect/discredit some others, promotes the existence of "good" and "bad" science. Accordingly, the differences between the two groups suggest that political orientation plays a role in supporting scientific consensus around CC.

Generalising these results to the four nations of the UK and covering the nuances in media framings, such as national-regional dimensions, is limited. Moreover, this study tried to provide a comprehensive picture of UK newspapers reporting by including both news and editorials (Boykoff, 2007; Boykoff \& Mansfield, 2008). However, the study did not distinguish between the two types of articles and distinctive characteristics in terms of framing and narratives cannot be derived at this stage.

\section{Conflict of interest}

The authors declare no conflict of interests.

\section{Supplementary Material}

Supplementary material for this article is available online in the format provided by the authors (unedited).

https://www.hope.uzh.ch/scoms/article/ view/j.scoms.2021.02.004

\section{References}

Abraham, J. (2014, April 24). Wave goodbye to the stadium wave - global warming still caused by humans. The Guardian. 
Retrieved from https://www.theguardian. com/environment/climate-consensus-97per-cent/2014/apr/24/global-warminghuman-caused-not-stadium-wave

Abraham, J. (2016, August 3). New research shows penguins will suffer in a warming world. The Guardian. Retrieved from https://www.theguardian.com/ environment/climate-consensus-97-percent/2016/aug/03/new-research-showspenguins-will-suffer-in-a-warming-world

Adam, D. (2010, April 23). Climate change scientist sues over online articles. The Guardian, p. 30 .

Akerlof, K., Rowan, K. E., Fitzgerald, D., \& Cedeno, A. Y. (2012). Communication of climate projections in US media amid politicization of model science. Nature Climate Change, 2(9), 648-654. https:// doi.org/10.1038/nclimate1542

Altheide, D. L., \& Snow, R. P. (1988). Toward a theory of mediation sage. In J. A. Anderson (Ed.), Communication Yearbook 11 (pp. 194-223). Beverly Hills, CA: Sage.

Anderson, A. (1997). Media, culture, and the environment. New Brunswick, Canada: Rutgers University Press.

Arnold, A. (2018). Climate change and storytelling. Cham, Switzerland: Palgrave. https:// doi.org/10.1007/978-3-319-69383-5

Ashdown, P. (2012, December 5). Fighting climate change is moral, vital, and in our own interests. The Independent. Retrieved from https://www.independent.co.uk/ voices/comment/un-climate-conferencefighting-climate-change-moral-vital-andour-own-interests-8386549.html

Associated Press (2016, March 4). There was NO pause in global warming. Daily Mail. Retrieved from http://www.dailymail.co.uk/ sciencetech/article-3477299/Revampedsatellite-data-shows-no-pause-globalwarming.html

Aukes, E. J., Bontje, L. E., \& Slinger, J. H. (2020). Narrative and frame analysis: Disentangling and refining two close relatives by means of a large infrastructural technology case. Forum: Qualitative Social Research, 21(2). http://dx.doi.org/10.17169/ fqs-21.2.3422

Austin, J. (2016, February 9). Melting ice caps could enrich ocean life and even slow climate change. The Express. Retrieved from https://www.express.co.uk/news/ science/642590/SHOCK-STUDY-Meltingice-caps-could-enrich-ocean-life-andeven-SLOW-climate-change

Avery, D. (1999, May 15). Welcome to the Garden of Eden. The Guardian. Retrieved from https://www.theguardian.com/ books/1999/may/15/books.guardianreview3

Bacon, W., \& Nash, C. (2012). Playing the media game. The relative (in)visibility of coal industry interests in media reporting of coal as a climate change issue in Australia. Journalism Studies, 13(2), 243-258. https:// doi.org/10.1080/1461670X.2011.646401

Batchelor, T. (2015, August 14). Climate change will "stop Britons holidaying in the Med", says shock new EU warning. The Express. Retrieved from https://www.express. co.uk/news/uk/598179/Climate-changeholidays-Spain-Portugal-EU-report

Beall, A. (2016, April 18). Could climate change lead to more food? Daily Mail. Retrieved from https://www.dailymail.co.uk/ sciencetech/article-3546151/Could-climate-change-lead-food-Increased-carbon-dioxide-help-wheat-rice-soybeansgrow-efficiently.html

Bell, A. (1994). Media (mis)communication on the science of climate change. Public Understanding of Science, 3(3), 259-275. https://doi.org/10.1088/0963$6625 / 3 / 3 / 002$

Bellamy, D. (2004, July 9). Global warming? What a load of poppycock! Daily Mail, p. 12.

Berglez, P. (2011). Inside, outside, and beyond media logic: Journalistic creativity in climate reporting. Media, Culture \& Society, 33(3), 449-465. https://doi. org/10.1177/0163443710394903

Bishop, R. (2001). The pursuit of perfection: A narrative analysis of how women's magazines cover eating disorders. The Howard Journal of Communications, 12(4), 221-240. https://doi. org/10.1080/106461701753287732

Boholm, A. (2015). Anthropology and risk. London, UK: Routledge / Taylor \& Francis Group.

Booker, C. (2009, February 22). Climate change rhetoric spirals out of control. The Sunday Telegraph, p. 16. 
Boykoff, M. T. (2007). Flogging a dead norm? Newspaper coverage of anthropogenic climate change in the United States and United Kingdom from 2003 to 2006. Area, 39(4), 470-481. https://doi.org/10.1111/ j.1475-4762.2007.00769.x

Boykoff, M. T. (2008). The real swindle. Nature Climate Change, 1, 31-32. https://doi. org/10.1038/climate.2008.14

Boykoff, M. T. (2009). We speak for the trees: Media reporting on the environment. Annual Review of Environment and Resources, 34(1), 431-457. https://doi.org/10.1146/ annurev.environ.051308.084254

Boykoff, M. T. (2013). Public enemy No. 1? Understanding media representations of outlier views on climate change. American $\mathrm{Be}$ havioral Scientist, 57(6), 796-817. https:// doi.org/10.1177/0002764213476846

Boykoff, M. T. (2014). Media discourse on the climate slowdown. Nature Climate Change, 4, 156-158. https://doi.org/10.1038/nclimate 2156

Boykoff, M. T., \& Boykoff, J. M. (2004). Balance as bias: Global warming and the US prestige press. Global Environmental Change, 14(2), 125-136. https://doi.org/10.1016/j. gloenvcha.2003.10.001

Boykoff, M. T., \& Mansfield, M. (2008). "Ye olde hot aire": Reporting on human contributions to climate change in the UK tabloid press. Environmental Research Letters, 3(2), 1-8. https://doi.org/10.1088/17489326/3/2/024002

Brockes, E., \& Borger, J. (2001, July 26). Tiger trap. The Guardian. Retrieved from https://www.theguardian.com/environment/2001/jul/26/climatechange.physicalsciences

Brown, A. (2012, August 21). If we are to cope with climate change we need a new moral order. The Guardian. Retrieved from https://www.theguardian.com/commentisfree/andrewbrown/2012/aug/21/confront-climate-change-moral

Brown, P. (1995, December 5). Rising sea levels, drought and the spread of disease are just some of the threats from global warming. The Guardian, p. 10.

Brown, P. (2000, November 2). Europe told there is no choice but to adapt. The Guardian, p. 6.
Brown, P., \& Vidal, J. (1997, October 29). Who killed Kyoto? The Guardian, p. 4.

Brüggemann, M. (2014). Between frame setting and frame sending: How journalists contribute to news frames. Communication Theory, 24(1), 61-82. https://doi. org/10.1111/comt.12027

Bruner, J. (1991). The narrative construction of reality. Critical Inquiry, 18(1), 1-21.

Cappella, J. N., \& Jamieson, K. H. (1997). Spiral of cynicism: The press and the public good. New York, NY: Oxford University Press.

Carpenter, J. (2011, November 1). Is global warming over? The Express, p. 28.

Carrell, S. (2012, April 6). Nasa scientist: Climate change is a moral issue on a par with slavery. The Guardian. Retrieved from https://www.theguardian.com/environment/2012/apr/06/nasa-scientist-climate-change

Carter, C. (2014, May 16). Global warming research suppressed due to intolerance of scepticism, claims scientist. The Daily Telegraph. Retrieved from https://www. telegraph.co.uk/news/earth/environment/climatechange/10835291/Scientists-accused-of-suppressing-research-because-of-climate-sceptic-argument.html

Carvalho, A. (2005). Representing the politics of the greenhouse effect. Critical Discourse Studies, 2(1), 1-29. https://doi. org/10.1080/17405900500052143

Carvalho, A. (2007). Ideological cultures and media discourses on scientific knowledge: Re-reading news on climate change. Public Understanding of Science, 16(2), 223-243. https://doi. org/10.1177/0963662506066775

Chong, D., \& Druckman, J. N. (2007). Framing theory. Annual Review of Political Science, 10, 103-126. https://doi.org/10.1146/annurev.polisci.10.072805.103054

Clark, R. (2005, January 2). Disasters don't kill people: Poverty does. The Sunday Telegraph, p. 23.

Clark, R. (2013, September 21). Global warming lobby has got it completely wrong. The Express. Retrieved from https://www. express.co.uk/comment/expresscomment/431081/Global-warming-lobbyhas-got-it-completely-wrong 
Clover, C. (2007, April 6). Climate change "will put a third of all species at risk". The Daily Telegraph, p. 10.

Collins, N. (2004, November 22). Global warming can be bad or good. The Daily Telegraph, $\mathrm{p} 20$.

Collins, N. (2013, September 27). Environmentalists guide to climate change. The Daily Telegraph. Retrieved from https:// www.telegraph.co.uk/news/earth/environment/climatechange/10338617/ Climate-change-report-environmentalists-guide-to-climate-change.html

Connor, S. (2006, February 5). James Lovelock: "The lush, comfortable world we are used to is going rapidly". The Independent on Sunday. Retrieved from https://www. independent.co.uk/news/people/profiles/ james-lovelock-the-lush-comfortableworld-we-are-used-to-is-going-rapidly-343237.html

Connor, S. (2007, January 18). Hawking warns: We must recognise the catastrophic dangers of climate change. The Independent. Retrieved from https://www.independent. co.uk/environment/climate-change/ hawking-warns-we-must-recognisethe-catastrophic-dangers-of-climatechange-6229043.html

Connor, S. (2013, November 18). Global warming proponents and sceptics agree on one point: Study into myth of "pause" merits more research. The Independent. Retrieved from https://www.independent.co.uk/ climate-change/news/global-warmingproponents-and-sceptics-agree-on-onepoint-study-into-myth-of-pause-meritsmore-research-8947522.html

Connor, S. (2014, December 4). Global warming set to make 2014 the hottest year ever. The Independent, p. 11.

Connor, S. (2016, March 14). February was hottest month on record as "exceptional" Nasa figures show global warming surge. The Independent. Retrieved from https:// www.independent.co.uk/environment/climate-change-global-warming-nasa-february-hottest-month-on-record-a6930981. html

Corner, A., \& Groves, C. (2014). Breaking the climate change communication deadlock. Nature Climate Change, 4, 743-745. https://doi.org/10.1038/nclimate2348
Corner, A., Whitmarsh, L., \& Xenias, D. (2012). Uncertainty, scepticism and attitudes towards climate change: Biased assimilation and attitude polarisation. Climatic Change, 114(3-4), 463-478. https://doi. org/10.1007/s10584-012-0424-6

Dahlstrom, M. F. (2010). The role of causality in information acceptance in narratives: An example from science communication. Communication Research, 37(6), 857-875. https://doi. org/10.1177/0093650210362683

Daily Mail. (1992, June 9). Greenhouse effect that could provide a cure. Daily Mail, p. 99.

Daily Mail. (1994, September 12). Could the Greens have got it wrong? Daily Mail, p. 24.

Daily Mail. (2002, February 25). This global warming myth. Daily Mail, p. 22.

Daily Mail. (2012, August 1). Heavy lifting: Scientists say oceans and forests are still soaking up about half the greenhouse gases we emit. Daily Mail. Retrieved from http://www.dailymail.co.uk/sciencetech/ article-2182194/Heavy-lifting-Oceans-forests-soaking-half-greenhouse-gases-emitscientists.html

Delingpole, J. (2009, November 25). How the global warming industry is based on one MASSIVE lie. The Daily Telegraph. Retrieved from https://archive.is/PMnPr

Delingpole, J. (2011, July 6). There has been no global warming since 1998. The Daily Telegraph. Retrieved from https://archive. is/4viY

Delingpole, J. (2013, May 22). Climate change caused the Oklahoma tornado? The Daily Telegraph. Retrieved from https://web. archive.org/web/20130607173230/http:// blogs.telegraph.co.uk/news/jamesdelingpole/100218177/climate-change-causedthe-oklahoma-tornado-crikey-these-people-are-getting-desperate

Derbyshire, D. (2007, September 19). The deadly disease bound for Britain on warmer winds. Daily Mail, p. 32.

Doulton, H., \& Brown, K. (2009). Ten years to prevent catastrophe? Discourses of climate change and international development in the UK press. Global Environmental Change, 19(2), 191-202. https://doi. org/10.1016/j.gloenvcha.2008.10.004 
Dunlap, R. E., \& Jacques, P. J. (2013). Climate change denial books and conservative think tanks: Exploring the connection. American Behavioral Scientist, 57(6), 699-731. https://doi. org/10.1177/0002764213477096

Dunlap, R. E., \& McCright, A. M. (2010). Climate change denial: Sources, actors, and strategies. In C. Lever-Tracy (Ed.), Routledge Handbook of Climate Change and Society (pp. 240-259). New York, NY: Routledge.

Edwards, D., \& Cromwell, D. (2006). Guardians of power: The myth of the liberal media. London, UK: Pluto.

Elliott, L., \& Seager, A. (2007, November 28). Cut carbon by up to third to save poor. The Guardian, p. 16.

Entman, R. M. (1993). Framing: Toward clarification of a fractured paradigm. Journal of Communication, 43(4), 51-58. https://doi. org/10.1111/j.1460-2466.1993.tb01304.x

Fahy, D. (2017). Objectivity, false balance, and advocacy in news coverage of climate change. Oxford Research Encyclopaedia of Climate Science. https://doi.org/10.1093/ acrefore/9780190228620.013.345

Feldman, L., Myers, T. A., Hmielowski, J. D., \& Leiserowitz, A. (2014). The mutual reinforcement of media selectivity and effects: Testing the reinforcing spirals framework in the context of global warming. Journal of Communication, 64(4), 590-611. https://doi.org/10.1111/jcom.12108

Floersch, J., Longhofer, J. L., Kranke, D., \& Townsend, L. (2010). Integrating thematic, grounded theory and narrative analysis. Qualitative Social Work, 9(3), 407-425. https://doi. org/10.1177/1473325010362330

Fløttum, K., \& Gjerstad, Ø. (2017). Narratives in climate change discourse. WIRES Climate Change, 8(1), 1-15. https://doi. org/10.1002/wcc.429

Ford, J. D., \& King, D. (2015). Coverage and framing of climate change adaptation in the media: A review of influential North American newspapers during 1993-2013. Environmental Science and Policy, 48, 137-146. https://doi.org/10.1016/j.envsci.2014.12.003

Foss, S. K. (1996). Rhetorical criticism: Exploration \& practice. Prospect Heights, IL: Waveland.
Gamson, W. A., \& Modigliani, A. (1989). Media discourse and public opinion on nuclear power: A constructionist approach. American Journal of Sociology, 95(1), 1-37.

Gibson, T. A., Craig, R. T., Harper, A. C., \& Alpert, J. M. (2015). Covering global warming in dubious times: Environmental reporters in the new media ecosystem. Journalism, 17(4), 417-434. https://doi. org/10.1177/ 1464884914564845

Graham, C. (2013, September 29). The poster boys of climate change thrive in the icy Arctic: Polar bears defy concerns about their extinction. Daily Mail. Retrieved from https://www.dailymail.co.uk/news/ article-2436882/The-poster-boys-climatechange-thrive-icy-Arctic-Polar-bears-defyconcerns-extinction.html

Gray, R. (2012, February 18). Foreign aid cash spent tackling climate change. The Daily Telegraph. Retrieved from https://www. telegraph.co.uk/news/earth/environment/climatechange/9090830/Foreignaid-cash-spent-tackling-climate-change. html

Griffin, R. J., \& Dunwoody, S. (1997). Community structure and scientific framing of news about local environmental risks. Science Communication, 18(4), 362-384. https:// doi.org/10.1177/1075547097018004005

Grundmann, R., \& Scott, M. (2014). Disputed climate science in the media: Do countries matter? Public Understanding of Science, 23(2), 220-235. https://doi. org/10.1177/0963662512467732

Gusfield, J. R. (1989). Constructing the ownership of social problems: Fun and profit in the welfare state. Social Problems, 36(5), 431-441. https://doi.org/10.2307/3096810

Hanlon, M. (2006, January 31). An apocalyptic new book warns that within a few decades global warming will kill our planet. Daily Mail, p. 12.

Hardaker, P. (2007, February 4). The next few years are critical in the fight for the climate. The Sunday Telegraph, p. 16.

Harding, T., \& Martin, G. (2001, February 20). Price we could pay for global warming. The Daily Telegraph, p. 6.

Hardy, P. (2004, March 7). Clouds gather on future of US skiing global warming's "devastating effect” will see rain replace snow. The Sunday Telegraph, p. 4. 
Hawkes, N. (1990, September 25). Wakeham says "huge task" lies ahead on global warming. The Times. Retrieved from LexisNexis Academic database.

Hellsten, I., \& Vasileiadou, E. (2015). The creation of the climategate hype in blogs and newspapers: Mixed methods approach. Internet Research, 25(4), 589-609. https:// doi.org/10.1108/IntR-05-2014-0130

Highfield, R. (2004, September 29). Can these bugs save the planet? The Daily Telegraph, p. 18.

Hmielowski, J. D., \& Nisbet, E. C. (2016). "Maybe Yes, Maybe No?" Testing the indirect relationship of news use through ambivalence and strength of policy position on public engagement with climate change. Mass Communication and Society, 19(5), 650-670. https://doi.org/10.1080/1520543 6.2016 .1183029

Höppner, C. (2010). Rereading public opinion polls on climate change in the UK press. International Journal of Communication, 4, 977-1005. Retrieved from http://ijoc. org/index.php/ijoc/article/view/703/469

Hosenball, M. (1990, April 22). Is it a warmedup world or just a load of hot air? The Sunday Times, C6. Retrieved from LexisNexis Academic database.

Houghton, J. T., Jenkins, G. J., \& Ephraums, J. J. (Eds.) (1990). Climate change. The IPCC scientific assessment. Report prepared for IPCC by Working Group 1. Retrieved from https://www.ipcc.ch/site/assets/uploads/2018/03/ipcc_far_wg_I_full_report. pdf

Jang, S. M., \& Hart, P. S. (2015). Polarized frames on "climate change" and "global warming" across countries and states: Evidence from Twitter big data. Global Environmental Change, 32, 11-17. https://doi. org/10.1016/j.gloenvcha.2015.02.010

Jenkins, S. (2006, May 28). Global warming might not be so bad, if we keep our cool. The Sunday Times, p. 16.

Jennings, N., \& Hulme, M. (2010). UK newspaper (mis)representations of the potential for a collapse of the Thermohaline Circulation. Area, 42(4), 444-456. https://doi. org/10.1111/j.1475-4762.2009.00936.x

Jones, M. D., \& McBeth, M. K. (2010). A narrative policy framework: Clear enough to be wrong? Policy Studies Journal, 38(2),
329-353. https://doi.org/10.1111/j.15410072.2010.00364.x

King, D. (2005, February 3). A chemist ahead of his time. The Guardian. Retrieved from https://www.theguardian.com/science/2005/feb/03/lastword.environment

Kinley, R. (2017). Climate change after Paris: From turning point to transformation. Climate Policy, 17(1), 9-15. https://doi.org /10.1080/14693062.2016.1191009

Kunelius, R. (2014). Climate change challenges: An agenda for decentralized mediatisation research. In K. Lundby (Ed.), Mediatisation of communication (pp. 63-86). Berlin, Germany: De Gruyter.

Labov, W., \&Waletzky, J. (1997). Narrative analysis: Oral versions of personal experience. Journal of Narrative \& Life History, 7(1-4), 3-38. https://doi.org/10.1075/jnlh.7.02nar Lambie, D. (2005, August 14). Lift your glass to chateau Scotland. Sunday Express, p. 19.

Laurance, J. (2001, February 9). Climate change to kill thousands, Ministers warned. The Independent, p. 2.

Lawson, D. (2006, March 31). If these islands were vaporised, there would be no significant effect on the future of the world's climate. The Independent, p. 31.

Lawson, D. (2007, March 9). Global warming gurus set a bad example. The Independent, p. 48.

Lawson, D. (2008, April 11). As they tackle climate change, governments are starving the people they set out to help. The Independent, p. 34 .

Leake, J. (2005, January 23). Greenhouse gases may be given burial at sea. Sunday Times, p. 10.

Lean, G. (1995, March 26). Global warming puts Britain's climate down the plughole. The Independent, p. 18.

Leiserowitz, A. A., Maibach, E. W., Roser-Renouf, C., Smith, N., \& Dawson, E. (2012). Climategate, public opinion, and the loss of trust. American Behavioral Scientist, 57(6), 818-837. https://doi. org/10.1177/0002764212458272

Levy, D. L., \& Nielsen, R. K. (2010). The changing business of journalism and its implications for democracy. Oxford, UK: Reuters Institute for the Study of Journalism.

Levy, D. L., \& Rothenberg, S. (1999). Corporate strategy and climate change: Heterogene- 
ity and change in the global automobile industry. ENRP Discussion Paper E-99-13. Cambridge, MA: Harvard University.

Lineman, M., Do, Y., Kim, J. Y., \& Joo, G.-J. (2015). Talking about climate change and global warming. Plos One, 10(9), 1-12. https://doi.org/10.1371/journal. pone.0138996

Macalister, T. (2004, May 15). Corporates warm to climate change. The Guardian, p. 29.

Manzo, K. (2012). Earthworks: The geopolitical visions of climate change cartoons. Political Geography, 31(8), 481-494. https://doi. org/10.1016/j.polgeo.2012.09.001

Matthews, J. (2015). Maintaining a politicised climate of opinion? Examining how political framing and journalistic logic combine to shape speaking opportunities in UK elite newspaper reporting of climate change. Public Understanding of Science, 26(4), 467-480. https://doi. org/10.1177/0963662515599909

Matthews, R. (2000, November 5). Are we to blame for this? The Sunday Telegraph, p. 25.

Matthews, R. (2003, April 6). Middle Ages were warmer than today, say scientists. The Sunday Telegraph, p. 16.

McCarthy, M. (1989, August 7). Greenhouse effect clues off the Cornish coast. The Times. Retrieved from LexisNexis Academic database.

McCarthy, M. (1990, February 10). Scientists agree for first time on rate of global warming. The Times. Retrieved from LexisNexis Academic database.

McCarthy, M. (1992a, August 8). Wildlife brings warning of changes in climate. The Times. Retrieved from LexisNexis Academic database.

McCarthy, M. (1992b, August 31). Botanists monitor effects of global warming in Britain. The Times. Retrieved from LexisNexis Academic database.

McCright, A. M., \& Dunlap, R. E. (2003). Defeating Kyoto: The conservative movement's impact on U.S. climate change policy. Social Problems, 50(3), 348-373. https:// doi.org/10.1525/sp.2003.50.3.348

McKie, R. (2007, January 28). Experts split over climate danger to Antarctica. The Observer, p. 7 .
McQuail, D. (1994). Mass communication theory: An introduction. Thousand Oaks, CA: Sage.

Mediatique (2018). Overview of recent $d y$ namics in the UK press market. Report commissioned by the Department for Digital, Culture, Media \& Sport. London, UK: Mediatique Limited. Retrieved from https://assets.publishing.service.gov.uk/ government/uploads/system/uploads/ attachment_data/file/778155/180621_Mediatique_-_Overview_of_recent_dynamics_in_the_UK_press_market_-_Report_ for_DCMS.pdf

Monbiot, G. (2009, April 29). The media laps up fake controversy over climate change. The Guardian. Retrieved from https://www. theguardian.com/environment/georgemonbiot/2009/apr/29/george-monbiot-climate-change-scepticism

Moodie, A. (2015, November 12). Unilever and Tesla top list of companies leading the fight on climate change. The Guardian. Retrieved from https://www.theguardian. com/sustainable-business/2015/nov/12/ climate-survey-change-conference-unilever-tesla-united-nations

Morris, S., \& Jha, A. (2007, August 30). Climate warning raises long-term flood fears. The Guardian. Retrieved from https://www. theguardian.com/environment/2007/ aug/30/weather.flooding

Moser, S. C. (2010). Communicating climate change: History, challenges, processes and future directions. WIREs Climate Change, 1(1), 31-53. https://doi.org/10.1002/ wcc. 11

Moser, S. C. (2014). Communicating adaptation to climate change: The art and science of public engagement when climate change comes home. WIREs Climate Change, 5(3), 337-358. https://doi.org/10.1002/wcc.276

Mulvey, K., \& Shulman, S. (2015). The climate deception dossiers. Cambridge, MA: Union of Concerned Scientists. Retrieved from www.ucsusa.org/decadesofdeception

Myers, N. (1992, July 24). Into a greater unknown. The Guardian, p. 28.

Nerlich, B., \& Jaspal, R. (2014). Images of extreme weather: Symbolising human responses to climate change. Science as Culture, 23(2), 253-276. https://doi.org/10 $.1080 / 09505431.2013 .846311$ 
Nicholson-Lord, D. (1990, July 1). Greenhouse gas forecast toned down. The Independent, p. 5.

Nisbet, E. C., Cooper, K. E., \& Garrett, R. K. (2015). The partisan brain: How dissonant science messages lead conservatives and liberals to (dis)trust science. The Annals of the American Academy of Political and Social Science, 658(1), 36-66. https://doi. org/10.1177/0002716214555474

Nott, J. (2005, May 16). Will global warming put camel plan on ice? The Express, p. 31.

NRS (2017). Newsbrands. National Readership Survey. Retrieved from http://www.nrs. co.uk/latest-results/nrs-print-results/ newspapers-nrsprintresults/

Nuccitelli, D. (2014, February 14). MP Graham Stringer and CNN Crossfire get the $97 \%$ consensus on human-caused global warming wrong. The Guardian. Retrieved from https://www.theguardian.com/ environment/climate-consensus-97-percent/2014/feb/14/global-warming-consensus-stringer-cnn

Nuccitelli, D. (2015, December 8). Betting against global warming is a sure way to lose money. The Guardian. Retrieved from https://www.theguardian.com/ environment/climate-consensus-97-percent $/ 2015 / \mathrm{dec} / 08 /$ betting-against-globalwarming-is-a-sure-way-to-lose-money

O'Neill, S. J. (2013). Image matters: Climate change imagery in US, UK and Australian newspapers. Geoforum, 49, 10-19. https:// doi.org/10.1016/j.geoforum.2013.04.030

O'Neill, S. J., \& Smith, N. (2014). Climate change and visual imagery. WIREs Climate Change, 5(1), 73-87. https://doi. org/10.1002/wcc. 249

Painter, J., \& Ashe, T. (2012). Cross-national comparison of the presence of climate scepticism in the print media in six countries, 2007-10. Environmental Research Letters, 7(4), 1-8. https://doi. org/10.1088/1748-9326/7/4/044005

Painter, J., \& Gavin, N. T. (2015). Climate skepticism in British newspapers, 2007-2011. Environmental Communication, 10(4), 432-452. https://doi.org/10.1080/1752403 2.2014 .995193

Pearce, D. (1990, May 18). Hot billions riding on warm air. The Times. Retrieved from LexisNexis Academic database.
Pearce, D. (1993, August 15). A threat, or just more hot air? The Independent, p. 43.

Pearce, F. (2006, August 30). Scientists fear that global warming will bring climatic turbulence, with changes coming in big jumps rather than gradually. The Guardian, p. 8.

Perkins, P. (1993, November 1). Heat is on for weather forecasters. The Guardian, p. 16.

Phelan, S. (2014). Neoliberalism, media and the political. Hampshire, UK: Palgrave.

Phillips, M. (2006, January 13). Does this prove that global warming's all hot air? Daily Mail, p. 19.

Pilkington, E. (2008, May 24). Wallace Broecker was one of the first scientists to raise the alarm about global warming. The Guardian, p. 31.

Polletta, F. (2006). It was like a fever: Storytelling in protest and politics. Chicago, IL: University of Chicago Press.

Prigg, M. (2014, May 21). Another positive effect of global warming? Daily Mail. Retrieved from https://www.dailymail.co.uk/ sciencetech/article-2635492/Have-ANOTHER-positive-effect-global-warmingMelting-ice-sheets-dumping-planktonboosting-iron-earths-oceans.html

Radford, C. (2009, November 5). Global warming debate is too hot to handle. The Daily Telegraph. Retrieved from https:// www.telegraph.co.uk/comment/personal-view/6505623/Global-warming-debateis-too-hot-to-handle.html

Radulova, L. (2014, December 9). "The world is going forward and we are going backward". Daily Mail. Retrieved from http://www. dailymail.co.uk/news/article-2866247/ The-world-going-forward-going-backward-Australia-worst-performing-country-world-fighting-climate-change-oilproducer-SAUDI-ARABIA-us.html

Rahmstorf, S. (2012). Is journalism failing on climate? Environmental Research Letters, 7(4), 1-3. https://doi.org/10.1088/17489326/7/4/041003

Rebich-Hespanha, S., Rice, R. E., Montello, D. R., Retzloff, S., Tien, S., \& Hespanha, J. P. (2015). Image themes and frames in US print news stories about climate change. Environmental Communication, 9(4), 491-519. https://doi.org/10.1080/1752403 2.2014 .983534 
Rhomberg, M. (2010). Risk perceptions and public debates on climate change: A conceptualisation based on the theory of a functionally-differentiated society. $\mathrm{Me}$ dieKultur: Journal of media and communication research, 26(49), 55-67. https://doi. org/10.7146/mediekultur.v26i49.2354

Rice, R. E., Gustafson, A., \& Hoffman, Z. (2018). Frequent but accurate: A closer look at uncertainty and opinion divergence in climate change print news. Environmental Communication, 12(3), 301-321. https:// doi.org/10.1080/17524032.2018.1430046

Rick, U. K., Boykoff, M. T., \& Pielke Jr, R. A. (2011). Effective media reporting of sea level rise projections: 1989-2009. Environmental Research Letters, 6(1), 1-5. https:// doi.org/10.1088/1748-9326/6/1/014004

Rose, D. (2013, May 1). The great green con No. 1: The hard proof that finally shows global warming forecasts that are costing you billions were WRONG all along. Daily Mail. Retrieved from http://www. dailymail.co.uk/news/article-2294560/ The-great-green-1-The-hard-proof-finallyshows-global-warming-forecasts-costingbillions-WRONG-along.html

Roy, A. (1989, July 30). Greenhouse hots up in a hurry. The Sunday Times. Retrieved from LexisNexis Academic database.

Ruiu, M. L. (2021). Representation of climate change consequences in British newspapers. European Journal of Communication, 36(5), 478-493. https://doi. org/10.1177/0267323120978727

Scheufele, D. A. (1999). Framing as a theory of media effects. Journal of Communication, 49(1), 103-122. https://doi. org/10.1111/j.1460-2466.1999.tb02784.x

Scheufele, D. A., \& Tewksbury, D. (2007). Framing, agenda setting, and priming: The evolution of three media effects models. Journal of Communication, 57(1), 9-20. https://doi.org/10.1111/j.00219916.2007.00326.x

Schoon, N. (1989, July 18). MPs criticise lack of policies to fight greenhouse effect. The Independent. Retrieved from LexisNexis Academic database.

Searjeant, G. (2004, October 29). Do you want global warming, nuclear power or poverty? The Times, p. 69.
Searjeant, G. (2005, November 28). It's clean, it's cheap-warming to the appeal of nuclear power. The Times, p. 46.

Severson, A. W., \& Coleman, E. A. (2015). Moral frames and climate change policy attitudes. Social Science Quarterly, 96(5), 1277-1290. https://doi.org/10.1111/ ssqu. 12159

Shaw, C. (2013). Choosing a dangerous limit for climate change: Public representations of the decision-making process. Global Environmental Change, 23(2), 563-571. https:// doi.org/10.1016/j.gloenvcha.2012.12.012

Simons, P. (1997, December 1). Could global warming turn Britain into a new Siberia? Daily Mail, p. 8.

Simons, P. (1998, July 7). Whatever happened to dustbowl Britain? Daily Mail, p. 9.

Slezak, M. (2016, February 11). CSIRO chief says row over climate science cuts "more like religion than science". The Guardian. Retrieved from https://www.theguardian. com/australia-news/2016/feb/11/csirochief-compares-climate-change-cutsbacklash-to-oil-lobby

Smith, J. (2005). Dangerous news: Media decision making about climate change risk. Risk Analysis, 25(6), 1471-1482. https:// doi.org/10.1111/j.1539-6924.2005.00693.x

Smith, L. (2001, June 9). Badger revival is boosted by winter warming. The Times. Retrieved from LexisNexis Academic database.

Smith, T. (2010). Discourse and narrative. In R. R. Hall, L. Grindstaff, \& M.-C. Lo (Eds.), Handbook of cultural sociology (pp. 129138). London, UK: Routledge.

Spencer, B. (2014, April 11). Could we SUCK UP climate change? Daily Mail. Retrieved from http://www.dailymail.co.uk/sciencetech/article-2602474/Could-SUCK-UP-climate-change-Excess-carbon-dioxide-absorbed-specially-developed-crops.html

Stone, A. (2011, March 21). Lord Stern has seen changing attitudes on the environment across the world. The Daily Telegraph, p. 6 .

Stott, P. (2003, August 8). Claims about global warming are worse than hot air, they poison the atmosphere. The Times, p. 20.

Takahashi, B., Huang, K., Fico, F., \& Poulson, D. (2017). Climate change reporting in Great Lakes region newspapers: A comparative study of the use of expert sources. 
Environmental Communication, 11(1), 106-121. https://doi.org/10.1080/1752403 2.2016.1220967

The Guardian. (2007, October 6). Hope and fear in Bali. The Guardian, p. 32.

The Independent. (2011, September 17). A primer in climate change for doubters. The Independent. Retrieved from https://www. independent.co.uk/voices/editorials/leading-article-a-primer-in-climate-changefor-doubters-5329866.html

Thornhill, T. (2013, October 25). New Australian PM dismisses as "hogwash" claims of Climate Commission he stripped of state funding that bushfires were caused by global warming. Daily Mail. Retrieved from https://www.dailymail.co.uk/news/ article-2476502/New-Australian-PM-Tony-Abbott-dismisses-hogwash-claimsbushfires-caused-global-warming.html

Tickell, O. (1997, October 27). Scientists believe that by stimulating plankton growth they could prevent global warming. The Independent, p. 48.

Trumbo, C. (1996). Constructing climate change: Claims and frames in US news coverage of an environmental issue. Public Understanding of Science, 5(3), 269-283. https://doi.org/10.1088/0963$6625 / 5 / 3 / 006$

Tuchman, G. (1978). Making news: A study in the construction of reality. New York, NY: Free Press.

Tudge, C. (2013, April 3). Let's not bet the farm. The Guardian. Retrieved from https:// www.theguardian.com/commentisfree/2013/apr/03/lets-not-bet-the-farm

UNFCCC. (2006). Framework convention on climate change handbook. Bonn, Germany: Climate Change Secretariat.

Ungar, S. (1992). The rise and (relative) decline of global warming as a social problem. Sociological Quarterly, 33(4), 483-501. https://doi.org/10.1111/j.1533-8525.1992. tb00139.x

Ungar, S. (1995). Social scares and global warming: Beyond the Rio convention. Society \& Natural Resources, 8(5), 443-456. https:// doi.org/10.1080/08941929509380935

Ungar, S. (2001). Moral panic versus the risk society: The implications of the changing sites of social anxiety. The British Journal of Sociology, 52(2), 271-291. https://doi. org/10.1080/00071310120044980

van Rensburg, W., \& Head, B. W. (2017). Climate change scepticism: Reconsidering how to respond to core criticisms of climate science and policy. Sage Open, 7(4), 1-11. https://doi. org/10.1177/2158244017748983

Vaughan, A. (2010, January 5). Climate scepticism will increase. The Guardian, p. 2.

Vestergård, G. L. (2011). From journal to headline: The accuracy of climate science news in Danish high-quality newspapers. Journal of Science Communication, 10(2), 1-7. https://doi.org/10.22323/2.10020203

Vidal, J. (2006, December 16). Practical action lights up future for Nepalese villagers. The Guardian, p. 26.

von Burg, R. (2012). Decades away or The Day After Tomorrow? Rhetoric, film, and the global warming debate. Critical Studies in Media Communication, 29(1), 7-26. https://doi.org/10.1080/15295036.2011.6 37221

Wade, M. (2007, November 27). Scots scientists lead project to find crops for a warmer world. The Times, p. 9.

Warren, L. (2014, March 3). "I made a mistake": Gaia theory scientist James Lovelock admits he was "alarmist" about the impact of climate change. Daily Mail. Retrieved from https://www.dailymail.co.uk/news/article-2134092/Gaia-scientist-James-Lovelock-I-alarmist-climate-change.html

Webb, S., \& Smith, L. (2013, January 8). Is global warming as bad as first feared? Daily Mail. Retrieved from LexisNexis Academic database.

Webster, B. (2013, September 18). Climate change cynics "like those who denied HIV". The Times, p. 7.

Weingart, P., Engels, A., \& Pansegrau, P. (2000). Risks of communication: Discourses on climate change in science, politics, and the mass media. Public Understanding of Science, 9(3), 261-283. https://doi. org/10.1088/0963-6625/9/3/304

Wenger, J. (2016, July 21). Climate's too hot to handle. The Sun, p. 8.

White, H. (1981). The value of narrativity in the representation of reality. In W. J. T. Mitchell (Ed.), On narrative (pp. 1-24). Chicago, IL: University of Chicago Press. 
White, H. (1987). The content and the form: Narrative discourse and historical representation. Baltimore, MD: Johns Hopkins University Press.

Wilkins, L. (1993). Between facts and values: Print media coverage of the greenhouse effect, 1987-1990. Public Understanding of Science, 2(1), 71-84. https://doi. org/10.1088/0963-6625/2/1/005

Winter, S. (2004, August 8). Focus climate change sets pattern of humid heatwaves. Sunday Express, p. 21.
YouGov (2017). How left or right-wing are the UK's newspapers? Retrieved from https:// yougov.co.uk/topics/politics/articles-reports/2017/03/07/how-left-or-right-wingare-uks-newspapers

Zolfagharifard, E. (2014, August 27). Man-made global warming could be irreversible, leaked IPCC report claims. Daily Mail. Retrieved from http://www.dailymail. co.uk/sciencetech/article-2734947/ UN-panel-Global-warming-humancaused-dangerous.html 